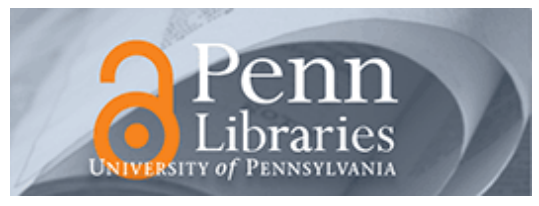

University of Pennsylvania

ScholarlyCommons

Management Papers

Wharton Faculty Research

6-1999

\title{
Who Gains From Trade Reform? Some Remaining Puzzles
}

Ann E. Harrison

University of Pennsylvania

Gordon Hanson

Follow this and additional works at: https://repository.upenn.edu/mgmt_papers

Part of the International Business Commons

Recommended Citation

Harrison, A. E., \& Hanson, G. (1999). Who Gains From Trade Reform? Some Remaining Puzzles. Journal of Development Economics, 59 (1), 125-154. http://dx.doi.org/10.1016/S0304-3878(99)00008-5

This paper is posted at ScholarlyCommons. https://repository.upenn.edu/mgmt_papers/157

For more information, please contact repository@pobox.upenn.edu. 


\title{
Who Gains From Trade Reform? Some Remaining Puzzles
}

\begin{abstract}
This paper focuses on three unresolved issues with regard to the impact of trade reform. First, many studies linking trade reform to long run growth are surprisingly fragile. To illustrate the problems with this literature, we examine a popular measure of openness recently introduced by Sachs and Warner [Sachs, J., Warner, A., 1995. Economic reform and the process of global integration. Brookings Papers on Economics Activity 1, pp. 1-117]. We show that their measure fails to establish a robust link between more open trade policies and long run growth. The second puzzle we identify is the small impact of trade reform on employment in developing countries. Finally, we analyze evidence on the relationship between trade reform and rising wage inequality, focusing on the 1985 Mexican trade reform. Wage inequality in Mexico rose after the reform, which is puzzling in a Heckscher-Ohlin context if Mexico has a comparative advantage in producing low skill-intensive goods.
\end{abstract}

\section{Keywords}

openness, trade policy, growth, wage inequality

Disciplines

International Business 
NBER WORKING PAPER SERIES

\title{
WHO GAINS FROM TRADE REFORM? SOME REMAINING PUZZLES
}

\author{
Ann Harrison \\ Gordon Hanson \\ Working Paper 6915 \\ http://www.nber.org/papers/w6915
}

\section{NATIONAL BUREAU OF ECONOMIC RESEARCH \\ 1050 Massachusetts Avenue \\ Cambridge, MA 02138 \\ January 1999}

\footnotetext{
The views expressed here are those of the author and do not reflect those of the National Bureau of Economic Research.

( 1999 by Ann Harrison and Gordon Hanson. All rights reserved. Short sections of text, not to exceed two paragraphs, may be quoted without explicit permission provided that full credit, including ${ }^{\circledR}$ notice, is given to the source.
} 
Who Gains from Trade Reform? Some Remaining Puzzles

Ann Harrison and Gordon Hanson

NBER Working Paper No. 6915

January 1999

JEL No. F13, F16

\title{
ABSTRACT
}

This paper focuses on three unresolved issues with regard to the impact of trade reform. First, many studies linking trade reform to long run growth are surprisingly fragile. To illustrate the problems with this literature, we examine a popular measure of openness recently introduced by Sachs and Warner (1995). We show that their measure fails to establish a robust link between more open trade policies and long run growth. The second puzzle we identify is the small impact of trade reform on employment in developing countries. Finally, we analyze evidence on the relationship between trade reform and rising wage inequality, focusing on the 1985 Mexican trade reform. Wage inequality in Mexico rose after the reform, which is puzzling in a Heckscher-Ohlin context if Mexico has a comparative advantage in producing low skill-intensive goods.

\author{
Ann Harrison \\ Columbia Business School \\ 615 Uris Hall \\ New York, New York 10027 \\ and NBER \\ aeh14@columbia.edu \\ Gordon Hanson \\ Department of Economics \\ University of Michigan \\ Ann Arbor, Michigan 48109 \\ and NBER \\ gohanson@umich.edu
}




\section{Introduction}

Most policy makers at the World Bank or IMF would argue that opening up to trade is an integral part of economic reform. In fact, many would argue that there are very few remaining puzzles regarding the benefits of trade reform. This attitude is evident from the changing fortunes of the Trade Policy Division at the World Bank, which was first removed from the Policy Research Department and then reinstated there. Although we do not dispute that trade reform is a well-researched area, the goal of this paper is to identify a number of remaining puzzles.

The focus of many previous studies has been to establish a link between trade policies and long run performance, measured in terms of either productivity or per capita growth. Although these studies typically show a positive relationship between trade reform and productivity growth, most are plagued by serious econometric and data problems. To illustrate the problems with this literature, we examine a popular measure of openness recently introduced by Sachs and Warner (1995). The evidence presented in this paper shows that their measure fails to establish a robust link between more open trade policies and long run growth. This is the first puzzle presented in this paper: why is it so difficult to identify a link between trade reform and long run growth? We argue that one major reason is the lack of good data on trade policies across countries and over time.

The second part of the paper moves from aggregate cross-country evidence to examine the micro evidence on the impact of trade reform. Do the rents from protection accrue to capital or to labor? Most developing country studies to date have focused on the impact of trade reform 
on the labor market. These studies typically find that the employment effects of trade reforms have been small. The small employment responses to very large changes in either trade policies or trade flows are puzzling. At the very least, one would expect a larger reallocation of employment away from import-competing sectors--in both developed and developing countries. Focusing in particular on Mexico and Morocco, this paper examines several explanations for the small employment and output response. In Morocco, much of the adjustment occurred through falling profit margins. In Mexico, much of the adjustment occurred through falling wages in previously protected, highly unionized sectors.

The paper concludes with a third puzzle. Do the costs of adjustment to trade reform fall disproportionately on unskilled workers? This issue has received widespread attention in the United States, where earnings inequality steadily increased during the 1980s. During this period, the wages of skilled workers in a number of developing countries--including Mexico--also rose relative to the wages of unskilled workers. To be consistent with the Stolper Samuelson (SS) theorem, the increased wage inequality observed in Mexico would have to reflect an increase in the relative price of skill-intensive goods. Yet if Mexico has a comparative advantage in producing goods that use unskilled labor, we would have expected trade reform to lead to a decline in the relative price of skill-intensive goods. The puzzle can be resolved by examining both the pattern of protection in Mexico and the role of other factors (such as direct foreign investment) during the 1980s.

The remainder of the paper is organized as follows. Section I examines the evidence on the relationship between trade policies and long run growth. Section II summarizes the impact of trade reform on wages, employment, and profit margins. Focusing in particular on Mexico and 
Morocco, we explore several explanations for the small employment and output response to large changes in tariffs and quotas. Finally, Section III discusses the relationship between rising wage inequality and trade reform in Mexico.

\section{Trade Policies and Long Run Growth}

\section{The Relationship between Trade and Growth}

Static trade models suggest that movements towards openness can temporarily increase the rate of growth due to short-run gains from the reallocation of resources, which would imply a positive relationship between changes in openness and GDP growth. The new growth literature also identifies a number of avenues through which openness might affect long run growth.

Edwards (1998), for example, shows that technological change is a positive function of both a country's openness and the gap between a country's technology level and the rest of the world. Intuitively, countries which are more backward and provide more opportunities to absorb new ideas will converge faster to international norms.

Coe and Helpman (1995) discuss how recent models of economic growth imply a positive relationship between openness to trade and total factor productivity growth, or TFP. Drawing on Grossman and Helpman (1991), they argue that differences in TFP can be explained by either an expanding number of inputs or higher input quality. To the extent that countries which are open to trade can either learn more quickly how to produce these new inputs, or can import them, openness will be positively related to TFP.

Grossman and Helpman (1991), however, show that in a theoretical framework, the relationship between opening up to trade and long run growth is in fact ambiguous. Whether or 
not a country gains from trade depends on a number of factors, including its comparative advantage vis-a-vis the rest of the world.

\section{The Evidence on Trade and Growth}

Although most of the early studies of the relationship between trade and growth find a consistently positive relationship, many of the more recent studies do not. This includes both cross-country comparisons of trade policies and GDP growth, as well as individual country case studies that examine intersectoral productivity growth and the nature of international competition. To illustrate the ongoing debate over the impact of trade policy in the long run, this section briefly reviews some recent studies on openness and growth.

One of the most frequently cited of the recent studies is Levine and Renelt (1992). Using half a dozen different measures of trade policies, the authors find no robust or even consistent positive relationship between opening up to trade and long run growth. As a test of robustness, they apply Leamer's (1985) extreme-bounds approach. Their measures of trade include the black market premium, Dollar's real exchange rate index of protection, trade volumes, and two indices compiled by Leamer. Yet they do find a robust, positive relationship between investment and trade shares, as well as between investment and the Leamer index. The correlation between investment and trade leads them to conclude that the beneficial effects of trade reform may operate through enhanced resource accumulation instead of through a more efficient allocation of resources.

Sala-i-Martin (1997) argues that Levine and Renelt's proposed test of robustness is too 
strong. He proposes an alternative test, which allows him to construct confidence levels for the entire distribution of coefficients for different determinants of long run growth. When he tests for robustness using this alternative approach, the only openness measure which is robust is a measure of openness constructed by Jeff Sachs and Andrew Warner. Yet we show below that their openness measure does not capture the impact of trade policy per se.

The evidence is no more conclusive for country studies which use detailed micro data to examine the relationship between productivity and openness to trade. Pack (1988) points out that "comparisons of total factor productivity growth among countries pursuing different international trade orientations do not reveal systematic differences in productivity growth in manufacturing..." Bhagwati (1988) writes that:
"Although the arguments for the success of the EP [Export Promotion] strategy based on economies of scale and X efficiency are plausible, empirical support for them is not available. The arguments on savings and innovation provide a less than compelling case for showing that EP is necessarily better on their account than IS [Import Substitution]"

Even the most recent efforts to examine the linkages between trade regimes and productivity growth, using more sophisticated econometric techniques and much better data than previous work, yield ambiguous results. Tybout (1992) reviews a number of his own and other studies for half a dozen developing countries, and concludes the following: 
"In view of the diverse, ambiguous theoretical literature on the link between trade and productivity, it is not surprising that stable, predictable correlations have not emerged."

\section{Using Sachs and Warner to Illustrate Lack of Robustness ${ }^{1}$}

The problems associated with identifying robust relationships between trade reform and growth is nowhere better illustrated than in a recent Brookings paper by Jeff Sachs and Andrew Warner (Sachs and Warner, (1995)). Using a new measure of openness, the authors conclude there is "strong evidence that protectionist trade policies reduce overall growth..." (p. 51). Yet their openness measure is a composite index of trade, exchange rate, and other policies, all of which could have very different effects on growth.

Sachs and Warner define an economy as closed if it satisfies at least one of the following conditions:

(1) Tariffs in the mid-1970s were 40 percent or more

(2) Quotas in the mid-1980s were 40 percent or more

(3) The black market premium (computed separately for the 1970s and 1980s)

was 20 percent or higher in either the 1970s or 1980s

(4) The country had a state monopoly on major exports

(5) The country had a socialist economic system

\footnotetext{
${ }^{1}$ This section has benefited greatly from discussions with Francisco Rodriguez and Dani Rodrik and, who are doing concurrent research analyzing the impact of openness measures on growth.
} 
An economy is defined as open if none of the above five conditions is satisfied. Sachs and Warner find that their composite openness measure is significantly related to long run growth. As mentioned above, others, such as Sala-I-Martin, have used this measure to test the robustness of the association between openness and growth.

Clearly, however, the Sachs and Warner measure captures many other aspects of openness than pure trade policy. Quotas and tariffs, for example, provide a good measure of commercial policy, while the black market premium measures the importance of exchange rate distortions. To measure the impact of these policies separately, we estimate a cross-country growth regression which corresponds exactly to the specification presented by Sachs and Warner, except that we decompose their openness measure into its five separate components. The dependent variable is the average annual growth in real GDP per capita for the period 1970 through 1989. The results are reported in Table 1.

In column (1), our control variables include GDP in 1970, the investment to GDP ratio averaged over 1970 through 1989, primary and secondary enrollments in 1970, and the share of government consumption in GDP, also averaged over 1970 through 1989. The coefficients on all these controls are consistent with those from Sachs and Warner. The coefficient on initial GDP per capita is negative and significant, indicating conditional convergence. Investment and secondary school enrollments are positively and significantly correlated with GDP growth between 1970 and 1989. Government consumption is negatively and significantly correlated with growth.

In column (1), we only include tariffs and quotas out of the five factors used to construct 
the Sachs and Warner measure of openness. ${ }^{2}$ Both tariffs and quotas are insignificant. A joint Ftest of their significance, reported at the bottom of the table, indicates that the two variables are jointly statistically insignificant. Surprisingly, the two measures in the Sachs and Warner index which are most likely to capture trade policy are not correlated with growth.

The coefficients on all five factors which were used to construct the Sachs and Warner ("SW") openness measure are reported in column (2). Out of all the five factors, only one is significant: whether or not the country had a socialist economic system. The results in column (2) seem to suggest that the factor driving statistical significance behind the composite measure is the market structure of the economy, not its trade policy orientation. In column (3), we add other controls included in the SW specification: the number of revolutions and coups, the number of assassinations per million population, and a measure of the relative price of investment goods. With these controls, we find that the socialist dummy, the marketing board dummy and tariffs are significant, but quotas and the black market premium are not.

In the fourth column, we replace the average black market premium in the 1970s and 1980s with a dummy variable equal to 1 if the premium exceeded 20 percent in either the 1970 s or 1980s. This variable captures the possibility that exchange rate distortions are only costly if they are large. In this specification, we do find that exchange rate distortions negatively affect growth, but quotas and tariffs both become insignificant. Using the Sachs Warner data, the results suggest in three out of four columns that trade policy is not significantly correlated with long run growth. Exchange rate distortions, however, may be negatively correlated with growth.

2 Rodriguez and Rodrik suggest that a fairer test of the Wachs Warner idea using only tariffs and quotas might be to create a Sw-type dummy, but using only the relevant two critieria-a country is closed if either $t>.4$ or $\mathrm{NTB}>$.4. We have not done this. 
At the bottom of Table 1, we also report the results from a number of different F-tests that we conducted to test for joint significance. Since some variables could be correlated with each other, they might not appear as significant individually but they might be jointly significant. One way to test for this is to enter these variables individually, as we did in column (1), without the other variables. Another way to test for this is to do joint F-tests. As the results indicate, all of the variables which failed to be significant individually fail to be significant in joint tests of significance as well. Tariffs and quotas are only jointly significant with the black market premium if the latter is entered as a dummy. In this case, the variables are jointly significant only because the black market dummy is significant on its own.

The implications of the results in Table 1 are somewhat disturbing. Is it that case that no measure of trade policy is significantly associated with growth? Sala-i-Martin, in his tests of robustness, also fails to find any significant correlation between measures of trade policy and long run growth--with the exception of the composite openness measure. But as we have seen, the significance of that measure is driven by other factors--such as the socialist dummy and exchange rate distortions. Some could argue that since there is no robust theoretical presumption regarding the long run effects of openness on growth, these results are only surprising in light of the many papers which have found a positive relationship between the two.

\section{Right Idea, Wrong Data?}

One possible explanation for these results is that Sachs and Warner have not adequately measured trade policy. Their measures of tariffs (on intermediate goods only) and quotas are taken from UNCTAD, as collected by Robert Barro and Jong-Wha Lee. These data were 
gathered in the mid-1980s, which means that Sachs and Warner use end of period averages to test average period growth rates. Unfortunately, no time series on commercial policies are available, which explains why Sachs and Warner use end of period data.

One alternative is to use so-called "effective" tariffs, defined as tariff revenues on imports defined by import volumes. This measure of trade policy is not ideal. However, it is an objective measure which is available across countries and over time. It is also highly correlated with administrative tariffs: for 1985, the correlation coefficient between UNCTAD's tariff measure (as reported by Sachs and Warner (1995)) and effective tariffs was .60. This measure has only rarely been used to measure trade policy. One exception is Edwards $(1992,1997)$, which uses this measure to evaluate the relationship between openness and growth.

In Table 2, we replace the measures of tariffs and quotas employed by Sachs and Warner with the effective tariff. Columns (1) and (2) replicate the first two columns in the previous table, but replace SW's measures with our own. We replace end-of-period tariffs and quotas with effective tariffs averaged over the period; we replace their measures of the black market premium with a period average collected from Pick's Currency Yearbook. Using a specification similar to Sachs and Warner, we now show strong and significant independent effects of openness to trade. Both openness to trade and exchange rate policies have a significant impact on long run growth. The coefficient on tariffs, which varies between -.053 and -.059, suggests that an increase in tariffs (which vary from 0 to over 100) of 10 percentage points would lead to a reduction in annual average long run growth of .4 percent.

In the third column, we replace the average black market premium over the period with the dummy variable closest in spirit to Sachs and Warner: a dummy variable equal to one if the 
BMP was greater than 20 percent in the 1970s or 1980s. The results are essentially unchanged. It is interesting to compare the impact of exchange rate distortions with trade policy distortions on growth. In all three columns, the impact of exchange rate distortions implied by the estimated coefficient on the black market premium is much smaller than that for tariffs. Since the premia are typically between 0 and 1, a ten percentage point increase in the black market premium implies a reduction in GDP growth of between .1 and .13 percent. This is much smaller than the .4 percentage point reduction in GDP implied by a ten percentage point increase in tariffs.

Although these results seem quite robust, in column (4) we again see how difficult it is to make definitive statements about the relationship between openness and growth, particularly in a pure cross-section. If we add three dummy variables: one for the four East Asian tigers, one for Latin America, and one for India, the significance on the openness variables again disappears. The socialist dummy and the marketing board dummy are significant, but the openness variables are not. Nevertheless, by adding so many controls to such a limited number of observations, it is not surprising that the significance of many variables disappears. These exercises point to the limited validity of pure cross-section estimation; the use of panel data--which combine crosssection and time series data--is likely to yield more fruitful and more robust results (see, for example, Harrison (1996)).

\section{Trade Policies and Growth: A Research Agenda}

The problems associated with identifying the linkages between policies and performance could be addressed through three different avenues. First, better data on trade policies should be made available. Detailed data on tariffs and quotas are in fact collected by both the World Bank 
and the International Monetary Fund (IMF). At the World Bank, however, such data are often discarded after a trade policy loan is disbursed or appraised. A systematic effort to retain these data would allow researchers much greater scope for policy analysis. The IMF also collects data on trade policies annually, in part for its publication on Trade and Exchange Restrictions. Yet no effort is made to systematically report summary statistics--such as tariff means or standard deviations. Additional efforts would also have to be devoted to computerizing the information. Since significant resources are devoted to collecting information on trade policies at both institutions, the marginal costs of recording and storing such data should be low.

In addition to data collection efforts, research efforts need to focus on solving the endogeneity problems associated with the relationship between trade policies and growth. Does openness cause growth? Or is it the other way around? One promising avenue of empirical research would be to apply the emerging literature on the political economy of trade policy. Political economy models of protection could help to determine what instruments to use for trade policy, which is clearly not exogenous. Trefler (1993), for example, shows that the impact of US trade restrictions on import flows are ten times larger than previously believed, in part because researchers neglected to account for the simultaneity of policy determination and import volumes. This same approach could be applied to the literature on productivity and long run growth. Another clever way to address the simultaneity problem is proposed by Frankel and Romer (1996). They use geographic proximity as an instrument for bilateral trade flows, which they then aggregate and use as an independent variable in the second stage to explain growth. However, it is difficult to argue that their measure explains the relationship between trade policy and growth, since their openness measure captures that part of trade which can only be explained by 
geography.

Finally, research needs to address the independent roles of both exchange rate (macro) policy and commercial policies. Black market premia are often used as a proxy for openness, but may have very different effects than tariffs or quotas in the long run. Based on Tables 1 and 2, disentangling the effects of these policies seems very difficult in a pure cross-section of countries. Researchers should explore the impact of these policies using panel data, which combine crosscountry and time series data.

\section{Trade Policies and Labor Market Adjustment}

\section{Evidence on Trade Policy and Labor Market Adjustment}

One of the first attempts to measure the partial equilibrium effects of import competition is Grossman $(1986,1987)$. Grossman analyzed the impact of tariff protection in the United States, finding that wages are fairly unresponsive to (tariff-inclusive) import prices but that employment responses in some sectors have been quite significant. Grossman concludes from the low wage elasticities and higher employment elasticities that there is fairly high intersectoral labor mobility within the United States. Other cross-industry studies of the Unites States and Canada include Freeman and Katz (1991), Revenga (1992), and Gaston and Trefler (1993). These studies also find significant effects of changes in import competition on inter-sectoral changes in employment, but smaller effects on wages. In the United States and Canada, it appears that trade policy changes lead to employment reallocation across industries, with very little effects on wages.

Evidence on trade and employment linkages is weaker for developing countries.

Although Anne Krueger's book on trade and employment in developing countries appeared in the 
early 1980s, we actually know very little about the short-run impact of trade policy reforms on the labor market. Krueger (1983) summarizes a project sponsored by the National Bureau of Economic Research (NBER) to analyze the linkages between trade policies and employment in ten industrializing countries. The NBER studies focused on (1) measuring the relative labor intensity of exportables versus import-substituting production and (2) measuring the extent to which greater protection encourages a shift towards more capital-intensive means of production. Krueger and her colleagues hypothesized that moving towards a more neutral trade regime led to greater labor intensity in production. However, none of the case studies directly measured the actual impact of trade reforms on the labor market--the book merely hypothesizes that trade reform should lead to employment increases as the labor force shifts towards labor-intensive tradeables.

Partial equilibrium approaches, similar in spirit to the US studies, have recently been completed for Uruguay, Mexico, and Morocco. For Uruguay, which introduced trade reforms in 1979 and again in 1985, Rama (1994) used four-digit industry data between 1978 and 1986 to measure the impact of trade liberalization on employment reallocation and real wages in the manufacturing sector. The results show that trade reforms had a significant impact on the level of employment across manufacturing subsectors, but almost no impact on real wages. Reducing the protection rate within a sector by 1 percent led to an employment reduction of between .4 and .5 percent within the same year. These results suggest that during those years the labor market in Uruguay was fairly competitive, with significant employment reallocation between sectors after the reforms.

For Mexico and Morocco, however, employment and wage effects of the trade reforms 
during the 1980s were relatively modest. Revenga (1997), using plant-level data for Mexico, finds a moderate reduction in firm-level employment following reductions in tariff levels and quota coverage. According to her estimates, changes in tariffs had no impact on employment. Reductions in quotas had a significant but relatively small impact: her estimates suggest that a reduction in quota coverage from 90 percent to 10 percent of output was associated with a 2 to 3 percent decline in employment. Currie and Harrison (1997) find an even smaller impact on employment of trade reform in Morocco. Using plant-level data for Morocco between 1984 (when the trade reform began) and 1990, they find that employment in most manufacturing firms was unaffected by tariff reductions and the elimination of quotas. There was a significant employment response for firms only in some specific sectors--such as textiles and beverages. The 21 point decline in tariff protection for firms in the textiles, beverages, and apparel sectors was associated with a 6 percent decline in employment. Why was the extent of employment reallocation so low? We explore several possible explanations for the sluggish employment response, including rigidities in the labor market, below.

Labor Market Imperfections as an Explanation for Small Employment Responses to Large Trade Policy Changes: Mexico and Morocco

By industrial country standards, the trade reforms initiated in both Mexico and Morocco during the 1980s were enormous. In Morocco, the trade reform initiated in 1984 reduced the coverage of import licenses (quotas) from 41 percent to only 11 percent of all imports by 1990 . The maximum tariff fell from $165 \%$ to $45 \%$ during this period. In Mexico, the trade reforms initiated in 1985 led to a reduction in the average tariff from $23.5 \%$ to $12.5 \%$ in 1990 , and the 
maximum tariff was reduced from $100 \%$ to $20 \%$. Import licensing, which covered $92.2 \%$ of all imports in 1985, covered less than $20 \%$ of all imports by 1990. (It is unclear, however, whether these policy reforms translated into large changes in relative goods prices (Hanson and Harrison, forthcoming).) In contrast, the Canada-United States Free Trade Agreement (CUSTA) resulted in an overall reduction in Canadian tariffs of $2.5 \%$ between 1988 and 1991, and the maximum tariff reduction was under $9 \%$.

One puzzling aspect of trade reform in Mexico and Morocco is that it appears to have had a small impact on wages and the reallocation of employment. One possible explanation is that labor market policies such as hiring and firing costs, or minimum wages, preventing firms from responding to the reforms. Inability to fire may have prevented employers from reallocating production to more profitable areas of production; evidence for other countries such as India and Venezuela suggests that this may be the case. Minimum wage laws may also have inhibited wage flexibility and undermined international competitiveness, leading to the observed lack of a wage response.

One simple way to test whether imperfections in the labor markets are responsible for the low adjustment response is to examine changes in output, employment, and trade policies. If wages in both countries are flexible and labor adjustment is not costly, variations in employment should be highly correlated with variations in output. Lack of employment adjustment could then be explained by lack of output adjustment to changes in policies. If output levels only responded sluggishly to tariff and quota changes, then it would not be surprising if employment failed to respond as well.

Tables 3 and 4 report correlations between changes in output, employment, and trade 
policies for Mexico and Morocco. Particularly in Morocco, but also to a lesser extent in Mexico, the results confirm that employment responded significantly to output changes, but that both output and employment were not highly correlated with changes in trade policies. In Table 3, which reports the correlations for Morocco, the correlation coefficient between changes in output and employment is .31 for annual data and .48 for long period (from 1984 to 1990) changes. However, the correlations between changes in output and trade policies are small in magnitude and inconsistent. While tariff increases were positively associated with output changes, changes in quotas were negatively associated with output changes--although the correlation coefficient in both cases is very small. Consequently, it is not surprising that employment changes are only weakly correlated with changes in trade policies.

The results in Table 4, which reports correlations for Mexico, are similar but less dramatic. The correlation coefficient between output and employment changes is .09 in the short run and .13 in the long run. However, there is no consistent positive or negative correlation between changes in output or employment and our two measures of trade policy changes--quota coverage and tariff levels. The lower correlation coefficient between output and employment for Mexico than for Morocco suggests there is some basis for the assertion that labor mobility in Mexico is impeded by regulatory or other impediments. However, the primary issue highlighted by both Tables 3 and 4 is the lack of a large, consistent output response to trade policy changes over the short and long run.

In Morocco, other evidence confirms the hypothesis of a fairly fluid labor market. In principle, hiring and firing laws are quite severe. Private firms must first obtain permission from government bodies to fire permanent employees, and must then pay a severance payment to 
dismissed employees ranging from five weeks (for 5 years of service) up to 38 weeks (for 15 years of service). Yet in practice, it is unclear how important a role restrictions on dismissals actually play in allowing private sector enterprises to respond to trade reform. Restrictions on dismissals typically only apply to the largest, formal sector enterprises. In addition, many enterprises have responded to restrictions on firing permanent workers by hiring temporary employees, who can be easily dismissed. The share of temporary workers in manufacturing rose nearly by nearly twenty percentage points between 1984 and 1990 .

Currie and Harrison (1997) examined the extent to which a sluggish adjustment of the labor force could explain the low elasticities of employment and wage responses to trade reform in Morocco. Using a lagged adjustment model of labor demand to test the speed of adjustment in Morocco, they found that with the exception of parastatals, employment adjustment takes place within the year. Their econometric estimates are in the same range as most of the industrial country estimates surveyed by Hamermesh (1993). In terms of the speed of adjustment, private sector firms in Morocco are more like North American firms than European firms--the latter typically adjust employment more slowly. These comparisons support the contention that in Morocco, despite legislation which on paper appears to be quite restrictive, labor mobility is comparable to the United States--where there are essentially no restrictions on hiring or firing. Another possible impediment to labor market adjustment are minimum wage laws. In both Mexico and Morocco, minimum wage laws were in place when the trade reforms were introduced. To the extent that minimum wages were binding, they could in principle act as a barrier to downward wage adjustment, explaining the lack of any wage response to tariff and quota changes. In Morocco, the real value of the minimum wage rose by 4.4 percent annually 
during the 1980s, which suggests that it could have played an important role in the adjustment process.

In practice, however, the evidence suggests that the minimum wage was not a factor in preventing adjustment in either Mexico or Morocco. Bell (1994) analyzed both plant-level and household data for Mexico to measure compliance with minimum wages. In Mexico, the evidence suggests that a large fraction of individuals received earnings below the statutory minimum wage. Further evidence for Mexico also suggests that the minimum wage had no impact on overall labor demand. This reflects both poor compliance as well as the fact that the real value of the minimum wage fell by 30 percent between 1984 and 1990 .

For Morocco, Currie and Harrison (1997) also report evidence which suggests significant lack of compliance with minimum wage legislation. Using data for 1986, they report that average wages at the plant level were below the minimum wage for at least half of their sample. They also report discussions with labor inspectors which suggested that they were significantly understaffed and likely to address only the most serious labor code violations.

While labor-market regulations were not much modified during the process of trade reform in Mexico, capital-market regulations changed substantially. One possibility is that the deregulation of foreign investment may have swamped the effects of changes in trade policy. Concomitant with trade reform, the Mexican government removed many barriers to foreign investment, including limits on the foreign share of equity ownership in a Mexican firm and requirements that foreign firms obtain government approval for technology transfer from abroad. Following these changes there was a dramatic increase in foreign investment, particularly in assembly plants known as maquiladoras. The expansion of foreign assembly plants in Mexico is 
the counterpart to the expansion of outsourcing by foreign firms, mainly in the United States. Feenstra and Hanson (1997) examine whether the shift from domestic manufacturing into foreign assembly has influenced the demand for skilled and unskilled labor in Mexico. For regional manufacturing industries, they find that the relative demand for skilled labor is positively correlated with the change in the number of foreign off-shore assembly plants, which suggests that foreign direct investment may have contributed to increasing wage inequality in Mexico.

\section{Alternative Explanations for the Lack of an Output Response}

The correlations presented in Tables 3 and 4 suggest that the sluggish employment response can be attributed to lack of an output response to quota and tariff changes in the two countries. How do we explain the fact that output did not seem to adjust to reductions in quotas and tariffs? In Mexico and Morocco, the explanation is three-fold. First, a real exchange rate depreciation initiated in conjunction with the reforms cushioned in the impact on firms. Second, firms in both countries increased productivity. Finally, firms in Mexico and Morocco maintained output (and consequently employment) by cutting profit margins (in Mexico and Morocco) and cutting wages (in Mexico).

One way to assess the impact of the trade reform is to examine changes in import competition. Although many economists would argue that the appropriate measures of trade policy changes are quotas and tariffs, changes in import volumes provide some insights into the actual impact of those policy changes.

Between 1984 and 1990, import penetration essentially remained unchanged in Morocco. Import penetration in the Moroccan manufacturing sector fluctuated from $37.6 \%$ in 1984, to 36.7 
$\%$ in 1987 , and finally increased slightly to 39 percent in 1990 . In other words, there was almost no change in actual imports as a share of domestic sales. The trend in Mexico during the 1980s is the same. In 1984, import penetration in Mexican manufacturing was 12.7 percent. That share declined to 8.7 percent in 1987, and then recovered, doubling to 16.2 percent in 1990. In light of these small changes in import competition, it is not surprising that output failed to respond.

Why did import penetration in manufacturing, which was certainly the most protected sector in Morocco prior to trade reform, remain more or less constant throughout the 1980s? Although trade reforms in both countries were far-reaching, protection levels still remained high in comparison to the industrial countries. In Morocco, despite the elimination of quotas and tariff reduction, average tariffs remained above 30 percent throughout the 1980s. In both Morocco and Mexico, a real exchange rate depreciation cushioned the impact of the trade reforms. Compared to other developing countries during this period, the real exchange rate in Mexico and Morocco depreciated significantly in the mid-1980s, when trade reforms were introduced in both countries. In Mexico, however, the real exchange rate began to appreciate beginning in the late 1980s.

In part, the real exchange rate depreciation in both countries cushioned firms against the trade reforms. However, evidence from both countries shows that firms responded to the threat of more imports by cutting profits. In other words, the costs of adjustment were shared with capital. For Mexico, Venables and Wijnbergen (1993) show that trade reforms led to significant reductions in price-cost margins. For Morocco, Currie and Harrison (1997) and de Melo, Haddad and Horton (forthcoming) show that greater import competition led to significantly lower margins. For Morocco, one remaining puzzle is why the costs of adjustment were not shared (at least partially) by labor in the form of lower wages. Anecdotal evidence for Morocco suggests 
that profits were very high prior to the reform--possibly allowing manufacturers to sustain comfortable margins even after lowering prices to compete with the threat of imports. It also appears that labor has essentially no market power--allowing capital to collect the rents under protection and forcing capital to bear a large fraction of the costs of adjustment under trade reform.

For Mexico, Revenga (1997) finds that labor did share in the rents accruing to protected sectors prior to reform. Consequently, she finds that wages fell significantly in Mexico after the reform. She estimates that an average tariff reduction of 20 percentage points led to an implied wage reduction of 5 to 6 percent.

Finally, there is also evidence that firms responded to greater international competition by raising productivity, allowing them to achieve efficiency gains without shedding labor. Both Currie and Harrison (1997) as well as Haddad (1993) show an increase in firm-level productivity in Morocco following the trade reforms. Although the evidence for Mexico is somewhat inconclusive, there is also some evidence of an increase in productivity during the latter part of the 1980s.

\section{Wage Inequality and Globalization}

\section{General Equilibrium Issues}

We began this paper by reviewing the evidence on the relationship between trade and long run per capita growth. Despite the problems associated with measuring this relationship, there does seem to be a positive correlation between openness to trade and long run growth. Section II examined the extent to which the gains (or losses) from trade--at least in the short run--could be 
identified in micro level data. One of the themes which emerges is that even the expected shortrun costs due to reallocating the labor force have been quite small. One reason is that capital has shared the costs of adjustment. Another reason is that the productivity gains from opening up to trade--captured in the aggregate growth regressions--also appear in the micro data in the form of higher productivity for individual firms. In both Mexico and Morocco, many firms responded by cutting margins and raising productivity.

Although the results presented in Section II address the overall impact of trade on trade and labor, they do not analyze the distributional consequences of trade reform for skilled and unskilled labor. This is an issue which has been extensively studied for the United States and other developed countries, but much less so for developing countries. In this section, we focus on Mexico's experience with trade reform. Mexico is a particularly interesting case because wage inequality had been declining in the decades prior to reform in 1985. Following the trade reform, however, the ratio of skilled to unskilled wages increased dramatically.

In a world with mobile labor, the impact of trade reform on wage inequality should be analyzed in a general equilibrium context. Under the standard general equilibrium framework of the Heckscher-Ohlin model, trade reform could be associated with increasing inequality if opening up to trade increases the price of skill-intensive goods (the Stolper-Samuelson Theorem). In the Mexican context, this would imply one of two possible hypotheses: (1) Mexico has a comparative advantage in producing goods which are intensive in the use of skilled labor or (2) Mexico protected its labor intensive sectors prior to the trade reform.

Hanson and Harrison (forthcoming) present evidence which is consistent with the second hypothesis. They show that the most protected sectors in 1984, prior to the 1985 reform, were 
those sectors intensive in the use of unskilled labor. In particular, they find a negative and statistically significant correlation between skill intensity in 1984 and tariff protection. In addition, tariff declines were highest in sectors which were intensive in the use of unskilled labor. The positive correlation between high skill intensity in 1984 and the magnitude of trade reform-as measured by tariff reductions--is also statistically significant at the 5 percent level.

Evidence for other developing countries also suggests a pattern of protection at odds with comparative advantage. Currie and Harrison (1997) find that protection in Morocco was significantly higher in sectors with a higher share of unskilled workers, such as textiles and clothing. In Morocco, textile and clothing firms were at the same time highly protected and the most export oriented in the manufacturing subsector. Firms made significant profit margins on the protected domestic market and also exported abroad. Under trade reform, these firms expanded their export sales and reallocated employment.

The evidence for Mexico is consistent with the Stolper Samuelson theorem. Tariff reductions were greatest in sectors with were more intensive in the use of unskilled labor. In a small country which cannot affect world prices, changes in tariffs are an ideal measure of price changes. However, other factors--which are not incorporated in a Heckscher-Ohlin framework-could also have affected the relative returns to skill in Mexico. Alternative explanations for increasing wage inequality in Mexico include outsourcing, skill-biased technological change, falling real minimum wages, and the decline of union strength. Feenstra and Hanson (1997), for example, argue that one source of wage inequality in Mexico is the fact that labor demand by incoming foreign firms is skewed towards skilled workers

To address these possibilities, we turn to plant-level evidence on the factors that 
contribute to relative wage and relative employment changes. In departing from a general equilibrium framework, we no longer test for the importance of $\mathrm{H}-\mathrm{O}$ effects on wage inequality. In fact, if both skilled and unskilled labor are perfectly mobile across sectors, sector-specific changes in tariffs and quotas should have an insignificant impact on sector or plant-level wage inequality. However, the estimation presented below could be consistent with a specific factors model, where labor is the specific factor. For example, if skilled labor is specific to the export sector, while unskilled labor is specific to the importable sector, trade reform could be associated with increasing wage inequality in Mexico. These results are consistent with Revenga (1997), who argues that unionization gave workers sector-specific rents. The evidence presented in Revenga (1997) suggests that Mexican workers in manufacturing adjusted primarily through sector-specific wage declines, rather than through employment reallocation. In Morocco, where unions have no power, there was no evidence of sector-specific wage responses to the trade reform.

\section{Heterogeneous Responses Across Plants}

To motivate our empirical results, we briefly summarize the rationale for estimating cost share equations and then discuss our departure from this approach. Previous literature sometimes specifies a cost function in which technology enters as a separate input and in which changes in technology over time have a non-neutral effect on labor inputs as classified by skill type.

We specify the following restricted variable cost function: 


$$
T V C=f\left(W_{s}, W_{u}, K, Y, T\right)
$$

where $T V C$ is total variable costs, which we measure as total labor costs; $W_{s}$ is the wage of skilled workers, which we measure as the average wage of white-collar workers; $W_{u}$ is the wage of unskilled workers, which we measure as the average wage of blue-collar workers; $K$ is the stock of quasi-fixed plant and equipment; $Y$ is value added; and $T$ is an index of technology, which we assume is a function of time. Subscripts for individual plants are suppressed.

We assume that we can approximate equation (1) by the following translog function:

$$
\begin{gathered}
\ln T V C="{ }_{0}+"{ }_{y} \ln Y+\sum_{i}{ }_{i} \ln W_{i}+\$ \ln K+\frac{1}{2}\left({ }_{Y Y}(\ln Y)^{2}\right. \\
+\frac{1}{2} \sum_{i} \sum_{j}\left({ }_{i j} \ln W_{i} \ln W_{j}+\frac{1}{2} *(\ln K)^{2}+\sum_{i} \mathrm{D}_{Y i} \ln Y \ln W_{i}+\sum_{i} \mathrm{D}_{i} \ln W_{i} \ln K\right. \\
+\mathrm{B} \ln K \ln Y+\mathrm{N}_{t} t+\frac{1}{2} \mathrm{~N}_{t t} t^{2}+\mathrm{N}_{t Y} t \ln Y+\sum_{i} \mathrm{~N}_{t i} t \ln W_{i}+\mathrm{N}_{t K} t \ln K+,
\end{gathered}
$$

where $\epsilon$ is a disturbance term. Brown and Christensen (1981) give the formal derivation of the restricted translog cost function. Bartel and Lichtenberg (1987) and Berman, Bound, and Griliches (1994) also use a translog restricted variable-cost function to identify the effects of skill-biased technical change.

To obtain an expression for variable input demands, we apply Shephard's lemma, which states that $\delta \ln T V C / \delta W_{i}=S_{i}$, where $S_{i}=W_{i} L / \Sigma_{i} W_{i} L_{i}$, or that derivative of the restricted cost function with respect to the price of labor type $i$ equals the share of labor type $i$ in total labor costs. This allows us to define the variable cost share equation for variable input $i$ :

$$
S_{i}="_{i}+\mathrm{D}_{y i} \ln Y+\sum_{j}\left({ }_{i j} \ln W_{j}+\mathrm{D}_{i} \ln K+\mathrm{N}_{t i} t+<\right.
$$


Nevertheless, there are a number of problems associated with estimating (4). Relative wages and value-added both determine and are determined by cost shares. In addition, we would like to know whether shares are changing because wages are responding to technology shocks, or employment levels, or both. Consequently, instead of estimating (4) we estimate a reduced form for both relative wages and relative employment levels separately as a function of both technology shocks and capital stock, the two variables in (4) which are pre-determined. This allows to identify the separate effects of technology shocks on both relative wages and relative employment.

\section{Estimation Issues and Results}

We have annual data on 2,354 manufacturing plants from the Secretariat of Trade and Industrial promotion (SECOFI) for 1984 through 1990. We proceed to examine the observable characteristics of these plants which are correlated with the relative wages and relative employment of skilled workers. We do so by regressing the log ratio of white-collar to blue-collar wages and the $\log$ ratio of white-collar to blue-collar employment on measures of (i) plant and industry export activity, (ii) plant and industry foreign-ownership status, (iii) trade protection, (iv) plant technology characteristics, and (v) characteristics of labor-market institutions observed at the plant level. Levels regressions include dummy variables for the year, region, and two-digit industry. The sample is all plants for which we a complete set of observations on the variables described below. All regressions are weighted by the plant share of total employment and corrected for arbitrary heteroskedasticity.

Appendix Table A.1 lists the variables included in the analysis and gives variable definitions. The SECOFI sample classifies workers in two categories: obreros, who are equivalent to blue-collar workers, and empleados, who are equivalent to white-collar workers. The activities of blue-collar 
workers include machine operation, production supervision, repair, maintenance, and cleaning; those of white-collar workers include management, product development, administration, and general office tasks. We identify white-collar workers as skilled labor and blue-collar workers as unskilled labor. We measure earnings as the average annual salary for each type of worker in a given plant. Industry variables are defined at the four-digit level and measured excluding the plant on which the observation is taken. Variables that capture export orientation and foreign ownership status are the share of exports in total sales at the industry level, the share of industry employment in foreign-owned plants, a dummy variable that indicates whether a plant has positive exports, and a dummy variable that indicates whether a plant is foreign owned. We also include the industry average tariff rate, the average share of industry production that is covered by import licenses, and the product of the tariff rate and the import-license coverage rate.

Variables that capture technological change -- either disembodied or embodied in capital goods -- are the plant share of imported machinery in total machinery purchases, the plant share of imported materials in total material purchases, the plant shares of total equipment purchases and transportation equipment purchases in total investment, lagged plant total factor productivity, and royalty payments for patents, and copyrights or trademarks as a share of total plant sales. We also include dummy variables for the plant employment-size category and dummy variables for the plant capital-labor ratio by quintile. ${ }^{3}$ To control for institutional features of labor markets, we include plant shares of social-security contributions, non-wage payments, and profit-sharing with workers in total

\footnotetext{
3 The excluded categories are small firms (1-50 workers) and the first quintile of the capital-labor ratio.
} 
labor costs. ${ }^{4}$

Table 5 presents results for the relative-wage regressions. Relative wages are defined as the $\log$ ratio of white collar to blue-collar average annual average annual wages. ${ }^{5}$ To address the possibility of multicollinearity, we begin by regressing in the first column relative wages on the two trade policy variables without any other controls. We then redo the analysis in first differences in the second column. Unfortunately, due to very little time series variation in many of the other independent variable, we only redo (1) in first differences. In the third column, we add other measures of openness. In the fourth column we add technology and labor market institution variables. Finally, in the fifth column we add additional measures of technological change.

In columns (1) and (2), the results are mixed: high industry tariffs are associated with greater wage inequality, while high quotas are associated with the opposite. The second column reports the same regression in first differences: changes in relative wages were regressed on changes in tariffs and quotas. The results are again inconclusive: there is no statistically significant correlation between changes in relative wages and changes in trade policy.

In the next three columns, we redo the analysis, controlling for other measures of openness, technology, capital intensity, size, and labor market institutions. Consider first the results for export activity, foreign ownership, and trade protection. Plants that participate in foreign product or capital markets appear to pay relatively high wages to skilled labor. Relative wages are positively and significantly correlated with the industry share of exports in sales, indicating that the skilled-unskilled

4 Unfortunately, since non-wage payments, such as social-security contributions and payroll taxes, are not available separately for white-collar and blue-collar workers, we cannot assess the extent to which using wages versus total employer costs affects the observed shift in the returns to skill.

5 Results using average hourly wages in place of average annual wages and total hours in place of average annual employment are very similar to those described below. 
wage gap is higher in high-export industries. Relative wages are also positively correlated with plantlevel foreign investment, but not with sector-level FDI. These results suggest that foreign investment locates in sectors with more income inequality, but that foreign firms themselves pay a higher premium to skilled workers. Consistent with the results in columns (1) and (2), relative wages are not significantly correlated with tariff rates or import-license coverage rates.

Among the technology variables, only the share of royalty payments in plant sales is positively and significantly correlated with relative wages. This result suggests that the skilled-unskilled wage gap is higher in plants that upgrade their technology through licensing arrangements. No other technology variables are statistically significant. Other plant characteristics are also important in explaining variation in the skilled-unskilled wage gap. The relative wages of white-collar workers are higher in medium-size plants, with less than 750 workers. Relative white-collar wages are also higher in more capital-intensive plants. Most of the dummy variables for the capital-labor quintiles are positive and statistically significant, and all of the plant-size dummy variables are positive and generally statistically significant. Relative wages are positively correlated with the share of profit-sharing payments in plant labor costs, indicating that the wage gap is higher in plants that have profit-sharing arrangements. Finally, the increasingly less negative and significant coefficients on the year dummy variables indicate that there is a strong time trend towards increasing wage inequality that is not explained by observable plant or industry characteristics.

The OLS regressions with the relative employment of white-collar workers as the dependent variable are reported in Table 6. The impact of tariffs and quotas is again mixed, depending on the specification. Across the levels specifications, we generally find that high tariffs are negatively associated with relative skilled employment, while high quotas are positively associated with the 
relative employment of white-collar labor. Only the first differences are consistent for both tariffs and quotas: a reduction in protection is associated with an increase in the relative employment of whitecollar workers. This result is consistent with Hanson and Harrison (forthcoming), who find that the pattern of protection prior to reform was skewed towards protecting sectors with a high share of bluecollar employment.

Among the technology variables, the relative employment of white-collar labor is positively correlated with royalty payments and the use of imported machinery or material inputs, and negatively correlated with equipment investment. There is a strong positive correlation between the plant capitallabor ratio and the relative employment of white-collar workers for all but the largest plants. The relative employment of white-collar labor is negatively correlated with the share of social security payments and the share of profit-sharing payments in plant labor costs, which may indicate that plants with a stronger union presence -- and hence more mandated payments to labor -- employ relatively less white-collar labor.

Although tariff and quota levels are generally not significant in explaining relative wages and employment, as indicated by the results reported in Tables 5 and 6, this is not surprising. Proponents of a general equilibrium framework could simply argue that we cannot capture the impact in this partial equilibrium, plant-level analysis. However, the results do point to the importance of foreign investment, export orientation, and technological change (as captured by royalty payments) in driving wage inequality. Since there were significant changes in both foreign investment and export orientation during this period, with rapid increases in both, these results suggest that openness certainly does matter. Further analysis, on a sample with greater variation over time in many of the dependent variables, is needed to analyze the importance of these factors. Nevertheless, there are 
many still unexplained sources of increasing wage inequality in Mexico, as is clear from the significance of the time dummies in Table 5.

\section{Concluding Comments}

We began this paper with the claim that most policy makers consider our knowledge of trade policy to be complete. Our goal was to highlight some continuing puzzles in our understanding of the effects of trade reform. We began with an examination of the evidence on trade reform and long run growth. Our analysis suggests that many approaches to measuring "openness" are significantly flawed: as an illustration, we showed that recent work by Sachs and Warner (1995) is not robust.

We then turned to a discussion of the impact of trade reforms at the micro level. The puzzle that we focused on in this section was the small impact on employment of large changes in tariffs and quotas for at least two countries: Mexico and Morocco. We argued that focusing on labor market effects ignores other ways in which firms adjust to falling protection--such as reducing excess profits and raising productivity.

Finally, we concluded by analyzing the impact of trade reform on relative wages in Mexico.

During the 1980s in Mexico the wages of skilled workers rose relative to the those of unskilled workers. We assess the extent to which the increase in wage inequality was associated with the 1985 trade reform. To be consistent with the Stolper Samuelson (SS) theorem, the increased wage inequality observed in Mexico would have to reflect an increase in the relative price of skill-intensive goods. If tariffs fell less in skill-intensive sectors, this would be consistent with the observed increase in inequality. We discuss evidence suggesting that protection in Mexico was skewed towards lowskilled sectors prior to reform, and that tariffs fell most in sectors which had a higher share of unskilled 
workers in 1984. Although these observed changes in trade policy are consistent with the Stolper Samuelson theorem, we also present evidence from plant-level regressions suggesting that both foreign direct investment, export orientation, and technological change also played an important role in the observed increase in wage inequality. 


\section{Bibliography}

Bell, $\quad$ L., "The Impact of Minimum Wages in Mexico and Colombia", Journal of Labor Economics, 1997.

Bhagwati, Jagdish. 1988. "Export-promoting trade strategy: Issues and Evidence". The World Bank Research Observer, 3, 27-57.

Bhagwati, Jagdish. 1978. Foreign Trade Regimes and Economic Development: Anatomy and Consequences of Exchange Control Regimes. Ballinger Press for the National Bureau of Economic Research, Cambridge, Massachusetts.

Coe, D.T. $\quad$ and E. Helpman. 1995 (May).“International R\&D Spillovers”, European Economic Review, 39(5): 859-87.

Currie, J and A. Harrison, "Trade Reform and Labor Market Adjustment in Morocco", Journal of Labor Economics, 1997.

de Melo, J., M. Haddad, and B. Horton, "Exports and Industrial Performance during the Moroccan Trade liberalization", in J. Tybout and M. Roberts, forthcoming, Producer Heterogeneity and Performance in the Semi-Industrialized Countries, Oxford University Press.

Edwards, $\quad$ S. 1992. "Trade Orientation, Distortions, and Growth in Developing countries," Journal of Development Economics. 39:31-57.

Edwards, $\quad$ S. 1998 (March).. "Openness, Productivity, and Growth: What Do We Really Know?", Economic Journal , 108 (447): 383-98.

Feenstra, $\quad$ R.C., and G.H. Hanson. 1997. "Foreign Direct Investment and Relative Wages: Evidence from Mexico's Maquiladoras," Journal of International Economics, 42: 371-394.

Frankel, Jeffrey A. and David Romer, "Trade and Growth: An Empirical Investigation”, NBER Working Paper, No. 5476, March 1996.

Freeman, $\quad$ R. and L. Katz, "Industrial Wage and Employment Determination in an Open Economy", Immigration, Trade and the Labor Market, edited by John M. Abowd and Richard B. Freeman, University of Chicago Press, 1991.

Grossman, G., "Imports as a Cause of Injury: The Case of the U.S. Steel 
Industry", Journal of International Economics, 20:201-23, 1986.

Grossman, G., "The Employment and Wage Effects on Import Competition in the United States", Journal of International Economic Integration 2:1-23.

Grossman, G. and E. Helpman. 1991. Innovation and Growth in the Global Economy, Cambridge, Mass., MIT Press.

Haddad, M. 1992. "The Link Between Trade Liberalization and MultiFactor Productivity: the Case of Morocco", World Bank, mimeo.

Hanson, G. and A. Harrison. Forthcoming. "Trade and Wage Inequality in Mexico". Industrial and Labor Relations Review.

Harrison, A. "Openness and Growth: A time-series, cross-country analysis for developing countries", Journal of Development Economics Vol. 48:419-447, 1996.

Krueger, A. O., Trade and Employment in Development Countries, Chicago, University of Chicago Press, 1983.

Levine, $\quad$ R. and D. Renelt. 1992. "A Sensitivity Analysis of Cross-Country Growth Regressions." American Economic Review, 82(4):942-963.

Rama, $\quad$ M., "The Labor Market and Trade Reform in Manufacturing", in The Effects of Protectionism on a Small Country, edited by Michael Connolly and Jaime de Melo, World Bank Regional and Sectoral Studies, Washington, D.C. 1994.

Revenga A., "Exporting Jobs? The Impact of Import Competition on Employment and Wages in U.S. Manufacturing", Quarterly Journal of Economics, February 1992.

Revenga A., "Employment and Wage Effects of Trade Liberalization: the Case of Mexican Manufacturing", Paper Prepared for World Bank Labor Markets Workshop, July 1994.

Sachs, J. and A. Warner, "Economic Reform and the Process of Global Integration", Brookings Papers on Economics Activity, 1: 1995, pages 1-117.

Trefler, D. 1993. "Trade Liberalization and the Theory of Endogenous Protection: An Econometric Study of U.S. Import Policy." Journal of Political Economy, vol 101, no. 1, February. 
Tybout, J. 1992. "Researching the Trade/Productivity Link: New Directions." The World Bank Economic Review, vol. 6, no. 2.

Tybout, J. R. and M. Daniel Westbrook. 1994. "Trade Liberalization and the Dimensions of Efficiency Change in Mexican Manufacturing Industries." Mimeo, Georgetown University.

Venables, A. J. and Sweder van Wijnbergen. 1993. "Trade liberalization, productivity, and competition: the Mexican Experience", mimeo. 
Table 1: Analyzing "Openness" in Sachs-Warner

Dependent Variable: A verage Growth in real GDP per capita, 1970-89

\begin{tabular}{|c|c|c|c|c|}
\hline $\begin{array}{l}\text { Independent } \\
\text { Variables }\end{array}$ & (1) & (2) & (3) & (4) \\
\hline Tariffs & $\begin{array}{l}-.315 \\
(-0.3) \\
\end{array}$ & $\begin{array}{l}-1.001 \\
(-1.0) \\
\end{array}$ & $\begin{array}{l}-2.092 \\
(-2.0) \\
\end{array}$ & $\begin{array}{l}-.793 \\
(-1.0) \\
\end{array}$ \\
\hline Quotas & $\begin{array}{l}-.661 \\
(-0.8) \\
\end{array}$ & $\begin{array}{l}-0.350 \\
(-0.4) \\
\end{array}$ & $\begin{array}{l}-.252 \\
(-0.3) \\
\end{array}$ & $\begin{array}{c}-0.551 \\
(-0.8) \\
\end{array}$ \\
\hline $\begin{array}{l}\text { Black Market } \\
\text { Premium in '70s }\end{array}$ & -- & $\begin{array}{c}-0.014 \\
(0.0)\end{array}$ & $\begin{array}{l}-.112 \\
(-0.4)\end{array}$ & -- \\
\hline $\begin{array}{l}\text { Black Market } \\
\text { Premium in '80s }\end{array}$ & -- & $\begin{array}{l}-0.233 \\
(-1.8)\end{array}$ & $\begin{array}{l}-.161 \\
(-1.3)\end{array}$ & -- \\
\hline $\begin{array}{l}\text { Black Market } \\
\text { Premium Dummy }\end{array}$ & -- & -- & -- & $\begin{array}{l}-1.605 \\
(-3.9)\end{array}$ \\
\hline $\begin{array}{l}\text { Marketing Board } \\
\text { Dummy }\end{array}$ & -- & $\begin{array}{l}-1.041 \\
(-1.3) \\
\end{array}$ & $\begin{array}{l}-1.489 \\
(-2.0) \\
\end{array}$ & $\begin{array}{l}-2.057 \\
(-3.3) \\
\end{array}$ \\
\hline Socialist Dummy & -- & $\begin{array}{l}-1.917 \\
(-2.5) \\
\end{array}$ & $\begin{array}{l}-2.066 \\
(-2.5) \\
\end{array}$ & $\begin{array}{c}-1.440 \\
(-1.7) \\
\end{array}$ \\
\hline GDP in 1970 & $\begin{array}{c}-1.319 \\
(-3.4) \\
\end{array}$ & $\begin{array}{c}-1.551 \\
(-4.1) \\
\end{array}$ & $\begin{array}{c}-1.481 \\
(-3.8) \\
\end{array}$ & $\begin{array}{c}-1.419 \\
(-4.2) \\
\end{array}$ \\
\hline $\begin{array}{l}\text { Ratio of Investment to } \\
\text { GDP }\end{array}$ & $\begin{array}{c}15.195 \\
(4.7) \\
\end{array}$ & $\begin{array}{c}12.284 \\
(3.7) \\
\end{array}$ & $\begin{array}{l}7.751 \\
(2.0) \\
\end{array}$ & $\begin{array}{c}6.653 \\
(1.8) \\
\end{array}$ \\
\hline $\begin{array}{l}\text { Primary Enrollment } \\
\text { in } 1970\end{array}$ & $\begin{array}{l}4.864 \\
(2.8) \\
\end{array}$ & $\begin{array}{l}-.392 \\
(-0.4) \\
\end{array}$ & $\begin{array}{l}-.298 \\
(-0.3) \\
\end{array}$ & $\begin{array}{l}.130 \\
(0.2) \\
\end{array}$ \\
\hline $\begin{array}{l}\text { Secondary } \\
\text { Enrollment in } 1970\end{array}$ & $\begin{array}{l}-.280 \\
(-0.3) \\
\end{array}$ & $\begin{array}{l}5.211 \\
(3.1) \\
\end{array}$ & $\begin{array}{c}4.793 \\
(2.6) \\
\end{array}$ & $\begin{array}{l}3.145 \\
(2.3) \\
\end{array}$ \\
\hline $\begin{array}{l}\text { Government } \\
\text { Consumption/ GDP }\end{array}$ & $\begin{array}{c}-7.449 \\
(-1.7) \\
\end{array}$ & $\begin{array}{l}-8.467 \\
(-2.1) \\
\end{array}$ & $\begin{array}{l}-6.820 \\
(-1.6) \\
\end{array}$ & $\begin{array}{c}-3.844 \\
(-1.0) \\
\end{array}$ \\
\hline $\begin{array}{l}\text { Revolutions and } \\
\text { Coups Dummy } 1 /\end{array}$ & -- & -- & $\begin{array}{l}-.648 \\
(-0.7) \\
\end{array}$ & $\begin{array}{l}-.236 \\
(-0.3) \\
\end{array}$ \\
\hline $\begin{array}{l}\text { Assassinations } \\
\text { Dummy } 2 /\end{array}$ & -- & -- & $\begin{array}{l}-2.896 \\
(-2.2) \\
\end{array}$ & $\begin{array}{c}-3.028 \\
(-2.3) \\
\end{array}$ \\
\hline $\begin{array}{l}\text { Relative Price of } \\
\text { Investment Goods 3/ }\end{array}$ & -- & -- & $\begin{array}{l}-1.092 \\
(-3.0)\end{array}$ & $\begin{array}{l}-.931 \\
(-2.4)\end{array}$ \\
\hline
\end{tabular}




\begin{tabular}{||l|c|c|c|c||}
\hline F-Value 4/ & 0.4 & 0.7 & 2.2 & 0.9 \\
\hline F-Value 5/ & -- & 2.0 & 1.4 & -- \\
\hline F-Value 6/ & -- & 1.5 & 1.9 & 5.5 \\
\hline $\begin{array}{l}\text { Number of } \\
\text { Observations }\end{array}$ & 72 & 72 & 71 & 71 \\
\hline R-square & .41 & .50 & .46 & .64 \\
\hline
\end{tabular}

Notes: T-statistics in parenthesis. All specifications corrected for arbitrary heteroskedasticity. For further

information on the variables used in Tables 1 and 2, see Sachs and Warner (1995).

1/ The number of revolutions and coupts per year, averaged over 1970-85

2 / The average number of assissinations per million population, 1970-85

3/ This is the deviation of the log of the price level of investment from the cross-country sample mean in 1970.

4/ Tests for the joint significance of Tariffs and Quotas.

5/ Tests for the joint significance of the Black Market Premium in the 1970s and 1980s.

6/ Tests for the joint significance of Tariffs, Quotas, and the Black Market Premium. 
Table 2: Does It Help to Use "Better" Data?

\begin{tabular}{|c|c|c|c|c|}
\hline $\begin{array}{l}\text { Independent } \\
\text { Variables }\end{array}$ & (1) & (2) & (3) & (4) \\
\hline $\begin{array}{l}\text { Effective Tariff } \\
\text { (Period A verage) }\end{array}$ & $\begin{array}{l}-.053 \\
(-2.6) \\
\end{array}$ & $\begin{array}{l}-.059 \\
(-2.9) \\
\end{array}$ & $\begin{array}{l}-.047 \\
(-2.2) \\
\end{array}$ & $\begin{array}{c}-0.023 \\
(-1.4) \\
\end{array}$ \\
\hline $\begin{array}{l}\text { Black Market } \\
\text { Premium (Period } \\
\text { Average) }\end{array}$ & $\begin{array}{l}-1.288 \\
(-2.7)\end{array}$ & $\begin{array}{l}-1.074 \\
(-2.3)\end{array}$ & -- & -- \\
\hline $\begin{array}{l}\text { Black Market } \\
\text { Premium Dummy }\end{array}$ & -- & -- & $\begin{array}{l}-.962 \\
(-2.6) \\
\end{array}$ & $\begin{array}{l}-.429 \\
(-1.2) \\
\end{array}$ \\
\hline $\begin{array}{l}\text { Marketing Board } \\
\text { Dummy }\end{array}$ & $\begin{array}{l}-1.523 \\
(-2.5)\end{array}$ & $\begin{array}{l}-1.803 \\
(-3.1)\end{array}$ & $\begin{array}{l}-1.979 \\
(-3.3)\end{array}$ & $\begin{array}{l}-2.386 \\
(-5.1)\end{array}$ \\
\hline Social ist Dummy & $\begin{array}{l}-1.079 \\
(-2.6) \\
\end{array}$ & $\begin{array}{l}-1.124 \\
(-2.5) \\
\end{array}$ & $\begin{array}{l}-1.893 \\
(-2.4) \\
\end{array}$ & $\begin{array}{l}-2.125 \\
(-5.0) \\
\end{array}$ \\
\hline GDP in 1970 & $\begin{array}{l}-1.542 \\
(-4.8) \\
\end{array}$ & $\begin{array}{l}-1.387 \\
(-3.9) \\
\end{array}$ & $\begin{array}{l}-1.417 \\
(-3.9) \\
\end{array}$ & $\begin{array}{l}-.921 \\
(-2.4) \\
\end{array}$ \\
\hline $\begin{array}{l}\text { Ratio of Investment to } \\
\text { GDP }\end{array}$ & $\begin{array}{c}10.139 \\
(3.4) \\
\end{array}$ & $\begin{array}{l}8.374 \\
(2.3) \\
\end{array}$ & $\begin{array}{l}7.136 \\
(1.8) \\
\end{array}$ & $\begin{array}{l}-.272 \\
(-0.1) \\
\end{array}$ \\
\hline $\begin{array}{l}\text { Primary Enrollment } \\
\text { in } 1970\end{array}$ & $\begin{array}{l}-.033 \\
(0.0) \\
\end{array}$ & $\begin{array}{l}-.122 \\
(-0.1) \\
\end{array}$ & $\begin{array}{l}.388 \\
(0.4) \\
\end{array}$ & $\begin{array}{l}1.862 \\
(2.0)\end{array}$ \\
\hline $\begin{array}{l}\text { Secondary } \\
\text { Enrollment in } 1970 \\
\end{array}$ & $\begin{array}{c}3.499 \\
(2.3) \\
\end{array}$ & $\begin{array}{l}2.967 \\
(1.8) \\
\end{array}$ & $\begin{array}{r}3.239 \\
(1.9) \\
\end{array}$ & $\begin{array}{c}2.390 \\
(1.5) \\
\end{array}$ \\
\hline $\begin{array}{l}\text { Government } \\
\text { Consumption/ GDP }\end{array}$ & $\begin{array}{l}-7.198 \\
(-2.20 \\
\end{array}$ & $\begin{array}{l}-5.087 \\
(-1.5) \\
\end{array}$ & $\begin{array}{l}-4.572 \\
(-1.20 \\
\end{array}$ & $\begin{array}{c}-4.150 \\
(-1.3) \\
\end{array}$ \\
\hline $\begin{array}{l}\text { Revolutions and } \\
\text { Coups Dummy } 1 \text { / }\end{array}$ & -- & $\begin{array}{c}-0.045 \\
(0.0) \\
\end{array}$ & $\begin{array}{l}.180 \\
(.2) \\
\end{array}$ & $\begin{array}{r}-0.097 \\
(-0.2) \\
\end{array}$ \\
\hline $\begin{array}{l}\text { Assassinations } \\
\text { Dummy } 2 /\end{array}$ & -- & $\begin{array}{c}-2.491 \\
(-2.1) \\
\end{array}$ & $\begin{array}{c}-2.900 \\
(-2.2) \\
\end{array}$ & $\begin{array}{r}-1.72 \\
(-1.4) \\
\end{array}$ \\
\hline $\begin{array}{l}\text { Relative Price of } \\
\text { Investment Goods 3/ }\end{array}$ & -- & $\begin{array}{l}-.874 \\
(-2.3)\end{array}$ & $\begin{array}{l}-.874 \\
(-2.3)\end{array}$ & $\begin{array}{l}1.862 \\
(2.0)\end{array}$ \\
\hline
\end{tabular}




\begin{tabular}{||l|c|c|c|c||}
\hline East A sia Dummy & No & No & No & Yes \\
\hline $\begin{array}{l}\text { Latin America } \\
\text { Dummy }\end{array}$ & No & No & No & Yes \\
\hline India Dummy & No & No & No & Yes \\
\hline F-Value & -- & -- & -- & 1.3 \\
\hline N & 75 & 73 & 71 & 73 \\
\hline R-square & .50 & .52 & .46 & .73 \\
\hline
\end{tabular}

Notes: T-statistics in parenthesis. All specifications corrected for arbitrary heteroskedasticity. For further information on the variables used in Tables 1 and 2, see Sachs and Warner (1995).

1/ The number of revolutions and coupts per year, averaged over 1970-85

2/ The average number of assissinations per million population, 1970-85

3/ This is the deviation of the log of the price level of investment from the cross-country sample mean in 1970.

4/ Tests for the joint significance of black market premium dummy and tariffs in columns (4). 
Table 3: Employment, Output and Trade Reform in Morocco M orocco, Year to Year Changes

\begin{tabular}{||l|c|c|c|c|c||}
\hline & $\begin{array}{c}\text { Log Change } \\
\text { in Output }\end{array}$ & $\begin{array}{c}\text { Log Change } \\
\text { in Number } \\
\text { of Workers }\end{array}$ & $\begin{array}{c}\text { Change in } \\
\text { Import } \\
\text { Penetration }\end{array}$ & $\begin{array}{c}\text { Change in } \\
\text { Tariffs }\end{array}$ & $\begin{array}{c}\text { Change in } \\
\text { Quota } \\
\text { Coverage }\end{array}$ \\
\hline $\begin{array}{l}\text { Log Change in } \\
\text { Output }\end{array}$ & 1.00 & 0.314 & -0.016 & 0.022 & -0.010 \\
\hline $\begin{array}{l}\text { Log Change in } \\
\text { Workers }\end{array}$ & & 1.00 & 0.005 & -0.008 & -0.010 \\
\hline $\begin{array}{l}\text { Change in Import } \\
\text { Penetration }\end{array}$ & & & 1.00 & -0.185 & -0.048 \\
\hline $\begin{array}{l}\text { Change in Tariffs } \\
\text { Change in Quota } \\
\text { Coverage }\end{array}$ & & & & 1.00 & 0.215 \\
\hline
\end{tabular}

Long Period Changes (1984 and 1990 Only)

\begin{tabular}{||l|c|c|c|c|c||}
\hline & $\begin{array}{c}\text { Log Change } \\
\text { in Output }\end{array}$ & $\begin{array}{c}\text { Log Change } \\
\text { in Number } \\
\text { of Workers }\end{array}$ & $\begin{array}{c}\text { Change in } \\
\text { Import } \\
\text { Penetration }\end{array}$ & $\begin{array}{c}\text { Change in } \\
\text { Tariffs }\end{array}$ & $\begin{array}{c}\text { Change in } \\
\text { Quota } \\
\text { Coverage }\end{array}$ \\
\hline $\begin{array}{l}\text { Log Change in } \\
\text { Output }\end{array}$ & 1.00 & 0.481 & -0.055 & 0.008 & -0.052 \\
\hline
\end{tabular}




\begin{tabular}{||l|l|l|l|l|l||}
\hline $\begin{array}{l}\text { Log Change in } \\
\text { Workers }\end{array}$ & 1.00 & -0.023 & -0.066 & -0.062 \\
\hline $\begin{array}{l}\text { Change in Import } \\
\text { Penetration }\end{array}$ & & & 1.00 & -0.255 & -0.039 \\
\hline Change in Tariffs & & & & 1.00 & 0.200 \\
\hline $\begin{array}{l}\text { Change in Quota } \\
\text { Coverage }\end{array}$ & & & & & 1.00 \\
\hline
\end{tabular}

Table 4: Employment, Output and Trade Reform in Mexico

Mexico, Year to Year Changes

\begin{tabular}{||l|c|c|c|c||}
\hline \hline & $\begin{array}{c}\text { Log Change } \\
\text { in Output }\end{array}$ & $\begin{array}{c}\text { Log Change } \\
\text { in N umber } \\
\text { of Workers }\end{array}$ & $\begin{array}{c}\text { Change in } \\
\text { Tariffs }\end{array}$ & $\begin{array}{c}\text { Change in } \\
\text { Quota } \\
\text { Coverage }\end{array}$ \\
\hline $\begin{array}{l}\text { Log Change in } \\
\text { Output }\end{array}$ & 1.00 & 0.092 & 0.025 & 0.058 \\
\hline $\begin{array}{l}\text { Log Change in } \\
\text { Workers }\end{array}$ & 1.00 & -0.010 & 0.056 \\
\hline $\begin{array}{l}\text { Change in Tariffs } \\
\text { Change in Quota } \\
\text { Coverage }\end{array}$ & & & 1.00 & -0.155 \\
\hline
\end{tabular}

Long Period Changes (1984 and 1990 Only)

\begin{tabular}{||l|c|c|c|c||}
\hline & $\begin{array}{c}\text { Log Change } \\
\text { in Output }\end{array}$ & $\begin{array}{c}\text { Log Change } \\
\text { in Number } \\
\text { of Workers }\end{array}$ & $\begin{array}{c}\text { Change in } \\
\text { Tariffs }\end{array}$ & $\begin{array}{c}\text { Change in } \\
\text { Quota } \\
\text { Coverage }\end{array}$ \\
\hline $\begin{array}{l}\text { Log Change in } \\
\text { Output }\end{array}$ & 1.00 & 0.133 & -0.087 & 0.174 \\
\hline
\end{tabular}




\begin{tabular}{||l|l|l|l|l||}
\hline $\begin{array}{l}\text { Log Change in } \\
\text { Workers }\end{array}$ & 1.00 & -0.057 & 0.000 \\
\hline Change in Tariffs & & & 1.00 & 0.112 \\
\hline $\begin{array}{l}\text { Change in Quota } \\
\text { Coverage }\end{array}$ & & & & 1.00 \\
\hline
\end{tabular}

Table 5: Variation in Relative White Collar Wages Across Plants

(T-Values in Parentheses)

\begin{tabular}{|c|c|c|c|c|c|}
\hline Dependent Variable: & Relative wage & $\begin{array}{c}\text { Change in } \\
\text { Relative wage }\end{array}$ & Relative wage & Relative wage & Relative wage \\
\hline & (1) & (2) & (3) & (4) & $(5)$ \\
\hline \multicolumn{6}{|l|}{ Trade Variables } \\
\hline $\begin{array}{l}\text { Export Share } \\
\text { (Industry) }\end{array}$ & - & - & $\begin{array}{l}.113 \\
(1.6)\end{array}$ & $\begin{array}{l}.118 \\
(1.7)\end{array}$ & $\begin{array}{l}.137 \\
(1.8)\end{array}$ \\
\hline $\begin{array}{c}\text { Foreign Share } \\
\text { (Industry) }\end{array}$ & - & - & $\begin{array}{l}-.068 \\
(-1.5)\end{array}$ & $\begin{array}{l}-.070 \\
(-1.5)\end{array}$ & $\begin{array}{l}-.088 \\
(-1.9)\end{array}$ \\
\hline Export Industry & - & - & $\begin{array}{l}.003 \\
(0.2)\end{array}$ & $\begin{array}{l}.004 \\
(0.2)\end{array}$ & $\begin{array}{l}.002 \\
(.1)\end{array}$ \\
\hline Foreign Dummy & - & - & $\begin{array}{l}.131 \\
(8.1)\end{array}$ & $\begin{array}{l}.127 \\
(7.9)\end{array}$ & $\begin{array}{l}.134 \\
(8.0)\end{array}$ \\
\hline Tariff (Tar) & $\begin{array}{c}2.853 \\
(8.5)\end{array}$ & - & $\begin{array}{c}-.00002 \\
(0.0)\end{array}$ & $\begin{array}{c}-00004 \\
(-0.3)\end{array}$ & $\begin{array}{c}-.0001 \\
(-0.1)\end{array}$ \\
\hline $\begin{array}{l}\text { Import } \\
\text { Licence }(\mathrm{QR})\end{array}$ & $\begin{array}{c}-1.306 \\
(-5.3)\end{array}$ & & $\begin{array}{l}.0001 \\
(0.3)\end{array}$ & $\begin{array}{l}.0001 \\
(0.2)\end{array}$ & $\begin{array}{l}.0002 \\
(0.4)\end{array}$ \\
\hline
\end{tabular}




\begin{tabular}{|c|c|c|c|c|c|}
\hline dTar & - & $\begin{array}{c}-.0013 \\
(-1.4)\end{array}$ & - & - & - \\
\hline dQR & - & $\begin{array}{c}-.0002 \\
(-0.8)\end{array}$ & - & - & - \\
\hline $\begin{array}{l}\text { Technology Variables } \\
\text { TPP (Lag) }\end{array}$ & - & - & - & $\begin{array}{l}.004 \\
(0.3)\end{array}$ & $\begin{array}{l}.005 \\
(0.4)\end{array}$ \\
\hline Royalty Payments & - & - & - & $\begin{array}{l}.090 \\
(2.2)\end{array}$ & $\begin{array}{l}.136 \\
(2.7)\end{array}$ \\
\hline Imported Machinery & - & - & - & - & $\begin{array}{l}.0004 \\
(0.0)\end{array}$ \\
\hline $\begin{array}{l}\text { Equipment } \\
\text { Investment }\end{array}$ & - & & & - & $\begin{array}{l}.034 \\
(1.4)\end{array}$ \\
\hline Imported Materials & - & - & - & - & $\begin{array}{l}-.063 \\
(-1.3)\end{array}$ \\
\hline
\end{tabular}




\begin{tabular}{|c|c|c|c|c|c|}
\hline $\begin{array}{c}\text { Average Plant Size: } \\
51 \text { to } 100\end{array}$ & - & - & $\begin{array}{l}.090 \\
(5.1)\end{array}$ & $\begin{array}{l}.088 \\
(5.0)\end{array}$ & $\begin{array}{l}.076 \\
(3.5)\end{array}$ \\
\hline 101 to 100 & - & - & $\begin{array}{l}.089 \\
(5.1)\end{array}$ & $\begin{array}{l}.088 \\
(5.0)\end{array}$ & $\begin{array}{l}.051 \\
(2.4)\end{array}$ \\
\hline 251 to 500 & - & - & $\begin{array}{l}.100 \\
(5.1)\end{array}$ & $\begin{array}{l}.100 \\
(5.0)\end{array}$ & $\begin{array}{l}.053 \\
(2.2)\end{array}$ \\
\hline 501 to 750 & - & - & $\begin{array}{l}.087 \\
(3.2)\end{array}$ & $\begin{array}{l}.084 \\
(3.0)\end{array}$ & $\begin{array}{l}.046 \\
(1.5)\end{array}$ \\
\hline 750 Workers & - & - & $\begin{array}{l}.004 \\
(0.2)\end{array}$ & $\begin{array}{l}.010 \\
(.4)\end{array}$ & $\begin{array}{l}-.032 \\
(-1.1)\end{array}$ \\
\hline $\begin{array}{l}\text { Capital-Labor Ratio } \\
2^{\text {nd }} \text { Quintile }\end{array}$ & - & - & $\begin{array}{l}.038 \\
(1.5)\end{array}$ & $\begin{array}{l}.036 \\
(1.4)\end{array}$ & $\begin{array}{l}.049 \\
(1.8)\end{array}$ \\
\hline $3^{\text {rd }}$ Quintile & - & - & $\begin{array}{l}.073 \\
(2.4)\end{array}$ & $\begin{array}{l}.074 \\
(2.6)\end{array}$ & $\begin{array}{l}.074 \\
(2.4)\end{array}$ \\
\hline $4^{\text {th }}$ Quintile & - & - & $\begin{array}{l}.133 \\
(5.1)\end{array}$ & $\begin{array}{l}.130 \\
(4.9)\end{array}$ & $\begin{array}{l}.141 \\
(.5 .0)\end{array}$ \\
\hline $5^{\text {th }}$ Quintile & - & - & $\begin{array}{l}.126 \\
(4.4)\end{array}$ & $\begin{array}{l}.116 \\
(3.8)\end{array}$ & $\begin{array}{l}.125 \\
(3.8)\end{array}$ \\
\hline $\begin{array}{l}\text { Labor Market Institutions } \\
\text { Social Security }\end{array}$ & - & - & - & $\begin{array}{l}-.138 \\
(-.5)\end{array}$ & $\begin{array}{l}-.192 \\
(-0.7)\end{array}$ \\
\hline Non-wage Costs & - & - & - & $\begin{array}{l}-.087 \\
(-0.7)\end{array}$ & $\begin{array}{l}-.081 \\
(-0.6)\end{array}$ \\
\hline Profit Sharing & - & - & - & $\begin{array}{l}.342 \\
(3.3)\end{array}$ & $\begin{array}{l}.336 \\
(3.1)\end{array}$ \\
\hline 1987 Year Dummy & $\begin{array}{l}.166 \\
(.3)\end{array}$ & $\begin{array}{c}-0.006 \\
(-0.3)\end{array}$ & $\begin{array}{l}-.231 \\
(-6.9)\end{array}$ & $\begin{array}{l}-.218 \\
(-6.5)\end{array}$ & $\begin{array}{l}-.224 \\
(-6.3)\end{array}$ \\
\hline 1988 Year Dummy & $\begin{array}{l}.155 \\
(.3) \\
\end{array}$ & $\begin{array}{l}.001 \\
(0.1) \\
\end{array}$ & $\begin{array}{l}-.224 \\
(-7.8) \\
\end{array}$ & $\begin{array}{l}-.211 \\
(-7.3) \\
\end{array}$ & $\begin{array}{l}-.226 \\
(-7.4) \\
\end{array}$ \\
\hline 1989 Year Dummy & $\begin{array}{l}.525 \\
(.1)\end{array}$ & $\begin{array}{l}.031 \\
(1.4)\end{array}$ & $\begin{array}{l}-.170 \\
(-7.5)\end{array}$ & $\begin{array}{l}-.167 \\
(-7.4)\end{array}$ & $\begin{array}{l}-.173 \\
(-7.1)\end{array}$ \\
\hline 1990 Year Dummy & $\begin{array}{l}-.138 \\
(0.0)\end{array}$ & $\begin{array}{l}.102 \\
(3.1)\end{array}$ & $\begin{array}{l}-.070 \\
(-2.3)\end{array}$ & $\begin{array}{l}-.072 \\
(-2.4)\end{array}$ & $\begin{array}{l}-.073 \\
(-2.2)\end{array}$ \\
\hline R-Square & .18 & .01 & .17 & .18 & .19 \\
\hline Number of Observations & 9355 & 9334 & 8021 & 8021 & 6652 \\
\hline
\end{tabular}

Note: All levels regressions include industry dummies and region (state) dummies, not reported here. 
Table 6: Determinants of the Variation in Relative White Collar Employment Across Plants

(T-Values in Parentheses)

\begin{tabular}{|c|c|c|c|c|c|}
\hline & $\begin{array}{c}\text { Relative } \\
\text { Employment }\end{array}$ & $\begin{array}{l}\text { Change in } \\
\text { Relative } \\
\text { Employment }\end{array}$ & $\begin{array}{c}\text { Relative } \\
\text { Employment }\end{array}$ & $\begin{array}{c}\text { Relative } \\
\text { Employment }\end{array}$ & $\begin{array}{l}\text { Relative } \\
\text { Employment }\end{array}$ \\
\hline & (1) & (2) & (3) & (4) & (5) \\
\hline \multicolumn{6}{|l|}{ Trade Variables } \\
\hline $\begin{array}{c}\text { Export Share } \\
\text { (Industry) }\end{array}$ & - & - & $\begin{array}{l}-.404 \\
(-3.7)\end{array}$ & $\begin{array}{l}-.417 \\
(-3.9)\end{array}$ & $\begin{array}{l}.366 \\
(-3.4)\end{array}$ \\
\hline $\begin{array}{l}\text { Foreign Share } \\
\text { (Industry) }\end{array}$ & - & - & $\begin{array}{l}.378 \\
(6.1)\end{array}$ & $\begin{array}{l}.365 \\
(5.9)\end{array}$ & $\begin{array}{l}.359 \\
(5.7)\end{array}$ \\
\hline Export Dummy & - & - & $\begin{array}{l}.092 \\
(3.4)\end{array}$ & $\begin{array}{l}.094 \\
(3.6)\end{array}$ & $\begin{array}{l}.058 \\
(2.1)\end{array}$ \\
\hline Foreign Dummy & - & - & $\begin{array}{l}.166 \\
(5.8)\end{array}$ & $\begin{array}{l}.165 \\
(5.9)\end{array}$ & $\begin{array}{l}.156 \\
(5.6)\end{array}$ \\
\hline Tariff (Tar) & $\begin{array}{l}.1030 \\
(3.7)\end{array}$ & - & $\begin{array}{l}-.0025 \\
(-1.4)\end{array}$ & $\begin{array}{l}-.0021 \\
(-1.2)\end{array}$ & $\begin{array}{c}-.0023 \\
(-1.3)\end{array}$ \\
\hline $\begin{array}{l}\text { Import } \\
\text { Licence (QR) }\end{array}$ & $\begin{array}{l}.0040 \\
(0.2)\end{array}$ & & $\begin{array}{l}.0013 \\
(2.4)\end{array}$ & $\begin{array}{l}.0014 \\
(2.6)\end{array}$ & $\begin{array}{l}.0013 \\
(2.3)\end{array}$ \\
\hline dTar & - & $\begin{array}{l}-.0008 \\
(-1.5)\end{array}$ & - & - & - \\
\hline $\mathrm{dQR}$ & - & $\begin{array}{l}-.0003 \\
(-3.4)\end{array}$ & - & - & - \\
\hline $\begin{array}{l}\text { Technology Variables } \\
\text { TPP (Lag) }\end{array}$ & - & - & - & $\begin{array}{l}.029 \\
(1.0)\end{array}$ & $\begin{array}{l}.027 \\
(.8)\end{array}$ \\
\hline Royalty Payments & - & - & - & $\begin{array}{l}.359 \\
(6.0)\end{array}$ & $\begin{array}{l}.272 \\
(3.9)\end{array}$ \\
\hline Imported Machinery & - & - & - & - & $\begin{array}{l}.593 \\
(7.2)\end{array}$ \\
\hline $\begin{array}{l}\text { Equipment } \\
\text { Investment }\end{array}$ & - & - & - & - & $\begin{array}{l}-.263 \\
(-6.8)\end{array}$ \\
\hline Imported Materials & - & - & - & - & $\begin{array}{l}.593 \\
(7.2)\end{array}$ \\
\hline
\end{tabular}




\begin{tabular}{|c|c|c|c|c|c|}
\hline $\begin{array}{c}\text { Average Plant Size: } \\
51 \text { to } 100\end{array}$ & - & - & $\begin{array}{l}.040 \\
(1.3)\end{array}$ & $\begin{array}{l}.044 \\
(1.4)\end{array}$ & $\begin{array}{l}-.0002 \\
(0.0)\end{array}$ \\
\hline 101 to 100 & - & - & $\begin{array}{l}.078 \\
(2.6)\end{array}$ & $\begin{array}{l}.073 \\
(2.4)\end{array}$ & $\begin{array}{l}.079 \\
(2.2)\end{array}$ \\
\hline 251 to 500 & - & - & $\begin{array}{l}.147 \\
(4.3)\end{array}$ & $\begin{array}{l}.140 \\
(4.0)\end{array}$ & $\begin{array}{l}.162 \\
(1.3)\end{array}$ \\
\hline 501 to 750 & - & - & $\begin{array}{l}.043 \\
(1 / 0)\end{array}$ & $\begin{array}{l}.039 \\
(0.9))\end{array}$ & $\begin{array}{l}.061 \\
(1.3)\end{array}$ \\
\hline 750 Workers & - & - & $\begin{array}{l}-.163 \\
(-4.1)\end{array}$ & $\begin{array}{l}-.174 \\
(-4.2)\end{array}$ & $\begin{array}{l}-.126 \\
(-2.7)\end{array}$ \\
\hline $\begin{array}{l}\text { Capital-Labor Ratio } \\
2^{\text {nd }} \text { Quintile }\end{array}$ & - & - & $\begin{array}{l}.317 \\
(8.1)\end{array}$ & $\begin{array}{l}.318 \\
(8.2)\end{array}$ & $\begin{array}{l}.291 \\
(6.7)\end{array}$ \\
\hline $3^{\text {rd }}$ Quintile & - & - & $\begin{array}{l}.355 \\
(8.9)\end{array}$ & $\begin{array}{l}.357 \\
(9.0)\end{array}$ & $\begin{array}{l}.360 \\
(8.4)\end{array}$ \\
\hline $4^{\text {th }}$ Quintile & - & - & $\begin{array}{l}.323 \\
(7.6)\end{array}$ & $\begin{array}{l}.322 \\
(7.5)\end{array}$ & $\begin{array}{l}.299 \\
(6.5)\end{array}$ \\
\hline $5^{\text {th }}$ Quintile & - & - & $\begin{array}{l}.151 \\
(3.5)\end{array}$ & $\begin{array}{l}.164 \\
(3.7) \\
\end{array}$ & $\begin{array}{l}.161 \\
(3.4) \\
\end{array}$ \\
\hline \multicolumn{6}{|l|}{ Labor Market Institutions } \\
\hline Social Security & - & - & - & $\begin{array}{l}-1.445 \\
(-4.35)\end{array}$ & $\begin{array}{r}-1.184 \\
(-3.1)\end{array}$ \\
\hline Non-wage Costs & - & - & - & $\begin{array}{l}.036 \\
(0.2)\end{array}$ & $\begin{array}{l}-.056 \\
(-0.4)\end{array}$ \\
\hline Profit Sharing & - & - & - & $\begin{array}{l}-.380 \\
(-2.7)\end{array}$ & $\begin{array}{l}-.363 \\
(-2.6)\end{array}$ \\
\hline 1987 Year Dummy & $\begin{array}{c}-.012 \\
(-.4)\end{array}$ & $\begin{array}{l}-.003 \\
(-1.0)\end{array}$ & $\begin{array}{l}.063 \\
(1.3)\end{array}$ & $\begin{array}{l}.040 \\
(.8)\end{array}$ & $\begin{array}{l}.043 \\
(0.4) \\
\end{array}$ \\
\hline 1988 Year Dummy & $\begin{array}{l}-.959 \\
(-0.4)\end{array}$ & $\begin{array}{l}.0012 \\
(0.1)\end{array}$ & $\begin{array}{l}.079 \\
(1.7)\end{array}$ & $\begin{array}{l}.055 \\
(1.2)\end{array}$ & $\begin{array}{l}.059 \\
(1.2)\end{array}$ \\
\hline 1989 Year Dummy & $\begin{array}{l}-.706 \\
(-0.3)\end{array}$ & $\begin{array}{l}-.021 \\
(-1.8)\end{array}$ & $\begin{array}{l}.016 \\
(.4)\end{array}$ & $\begin{array}{l}.030 \\
(.8)\end{array}$ & $\begin{array}{l}.035 \\
(.9)\end{array}$ \\
\hline 1990 Year Dummy & $\begin{array}{l}-.655 \\
(-0.2)\end{array}$ & $\begin{array}{l}-.020 \\
(-1.6)\end{array}$ & $\begin{array}{l}.016 \\
(.4)\end{array}$ & $\begin{array}{l}.021 \\
(.6)\end{array}$ & $\begin{array}{l}.031 \\
(.8)\end{array}$ \\
\hline R-Square & .57 & .00 & .35 & .36 & .39 \\
\hline Number of Observations & 9355 & 9337 & 8021 & 8021 & 6652 \\
\hline
\end{tabular}




\section{Appendix: Table A.1 Variable D efinitions}

$\underline{\text { Variable Definitions }}$

Export Share $^{\mathrm{a}:} \quad$ Industry share of total sales going to export markets.

Foreign Share $\quad$ Industry share of total employment in foreign-owned enterprises (with employment in foreign enterprises weighted by foreign-equity share).

Export Dummy: Equals one if plants has positive exports.

Foreign Dummy: $\quad$ Equals one if plant has positive foreign-equity participation.

Tariffa: $\quad$ Mean tariff (\%) on outputs by four-digit industry.

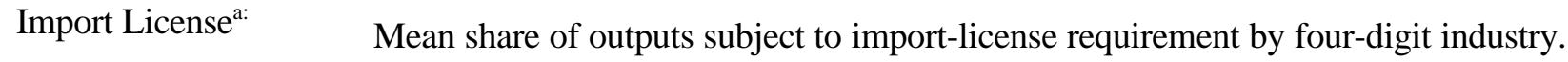

Imported Machinery Share of imported machinery in total machinery purchases.

Imported Materials: $\quad$ Share of imported material inputs in total material input purchases.

Equipment Investment: Share of equipment purchases in total investment.

Transport Share of transport equipment purchases in total investment.

Investment:

TFP

Percentage change in real output less weighted changes in material inputs, capital inputs, and number of employees, with weights given by the share of these inputs in total sales. Real output is defined as sales deflated by a four-digit product price deflator. Material inputs are deflated by a material price deflator.

Royalty Payments: $\quad$ Royalty payments for patents, copyrights, or trademarks as a share of total plant sales.

Capital-Labor Ratio: Reported capital stock valued at replacement rates (deflated by the PPI) / Number of Employees.

Social Security: $\quad$ Share of social-security contributions by the plant in total payroll costs.

Non-wage Costs: $\quad$ Share of other non-wage costs paid by the plant in total payroll costs.

Profit Sharing: $\quad$ Profit-sharing as a fraction of total payroll costs.

${ }^{\text {a }}$ Industry refers to the four-digit Mexican standard industrial classification (SIC). 